Carlo Amatucci, Professor of Law

University of Naples Federico II, Italy

\title{
CORPORATE SOCIAL RESPONSIBILITY AND THE QUEST FOR INCORPORATING STAKEHOLDERS' INTERESTS IN DIRECTORS' DUTIES
}

\begin{abstract}
Summary
CSR is an old debate in Company Law, and so are directors' duties in this regard. Last decades have seen the pre-eminence of the shareholder primacy, whereas a recent awareness of corporate externalities and of the necessity that directors take into account the effects of their decisions on stakeholders, is spreading in the literature and finding significant recognition in the law of some jurisdictions.

Keywords: corporate social responsibility, shareholders' primacy, stakeholders' interests, sustainability, externalities, directors' duties, the Accountable Capitalism Act, the UK Companies Act
\end{abstract}

\section{Introduction}

Despite the significant impact that companies have on society, the purpose they are supposed to achieve has been object of a very long debate among academics and law makers. Do companies have to increase shareholder wealth or do they have a wider responsibility to take into consideration stakeholders and society in general? In pursuing profits, do they have regard to externalities and should they manage to avoid them? Does the law require shareholder primacy or not?

\section{The corporate purpose}

The discussion on the "corporate social responsibility" is tightly linked to the duties of directors and dates back to the 1930s, to the well-known debate between Adolf Berle and Merrick Dodd ${ }^{1}$. Professor Berle argued that directors are trustees for the company's shareholders. He stated that all powers granted to the directors of a company are finalized to the benefit of shareholders. As the power

1 Macintosh J. C. C. The issues, effects and consequences of the Berle-Dodd debate, 1932-1932. Accounting, Organizations and Society, Vol. 24, 1999, pp. 139-153; O’Kelley C. R. T., Merrick Dodd and the great depression: a few historical corrections. SSRN, 2019. Available at: https://ssrn. com/abstract $=3325481$ [last viewed April 8, 2020]; Bratton W. W., Wachter M. L. Shareholder Primacy's Corporatist Origins: Adolf Berle and "The Modern Corporation". Journal of Corporation Law, Vol. 34, 2008, p. 99. 
to run a company had been delegated by the shareholders to the directors, they were responsible for running the corporation in the interests of the shareholders.

On the other hand, Professor Dodd argued that since corporation upon incorporation becomes a distinct legal entity, it has to serve not only the interests of shareholders but also those of other constituencies. He believed that directors were fiduciaries of the institution rather of its members.

For much of the $20^{\text {th }}$ century, American corporations tried to balance the interests of the stakeholders, including employees, customers, communities, with those of the shareholders. Still in the early 1980s, they dedicated less than a half of their profits to shareholders and reinvested the rest in the corporation itself.

Something happened during the 1980s. By the end of the decade, corporations adopted the belief that their only legitimate and legal purpose was to maximize "shareholder value". The debate became increasingly dominated by the law-andeconomics-inspired view of the company, considered as shareholders' property, as a "nexus of contracts", in which only the shareholders require protection. In replacement of the old conception was an ideology attributed mainly to the economist Milton Friedman, for whom

there is one and only one social responsibility of business - to use its resources and engage in activities designed to increase its profits so long as it stays within the rules of the game, which is to say, engages in open and free competition without deception or fraud ${ }^{2}$.

In 2001, Henry Hansmann and Reinier Kraakman stated that there was no longer any serious competitor to the view that corporate law should principally strive to increase long-term shareholder value. However, some U.S. states have enacted constituency statutes ${ }^{3}$, which permit, but generally do not require, directors to take into account the effects of a decision on stakeholders. Their conclusion was that shareholder primacy had become the dominant model of US corporate law.

Profits had become the only purpose of the corporation, committed to provide the highest possible returns for shareholders, disregarding the cost for society, employees, suppliers, and environment. Some American corporations dedicated over $90 \%$ of their earnings to shareholders.

\section{The resurgence of stakeholders' interests}

In 2011, Michael Porter and Mark Kramer suggested that the purpose of the corporation needs to be partially redefined. A corporation should

2 The social responsibility of business is to increase its profits. The New York Times Magazine, September 13, 1970. Available at: http://umich.edu/ thecore/doc/Friedman.pdf [last viewed October 31, 2019].

3 Hansmann H., Kraakman R. The End of History for Corporate Law. Georgetown Law Journal, Vol. 89, 2001, p. 439. 
integrate a social perspective into the core frameworks it already uses to understand competition and guide its business strategy. [..] Each company can identify the particular set of societal problems that it is best equipped to help resolve and from which it can gain the greatest competitive benefit ${ }^{4}$.

More recently, it has been pointed out ${ }^{5}$ that the shareholder primacy is the main barrier to sustainable companies and has flourished because regulations never clearly specified the definition of societal purpose of companies. Specifically, considering the so-called "intergenerational environmental justice", it must be admitted that

corporate governance can no longer be premised on shareholder primacy. Rather, an environmentally sustainable approach to corporate law ought to regulate the decisionmaking power of directors to ensure that the interests of future generations in the natural environment are taken into account ${ }^{6}$.

Again, with regard to sustainability, it has been conveniently said that CSR should "entail an integration of environmental and social concerns in the decisionmaking of the company in such a way as to lead to an internalization of externalities" The phenomenon of externality is crucial in the definition of what CSR really is. Among the different meanings, the one that, to my view, is to be preferred, considers CSR

the process by which companies identify and voluntarily neutralise the harmful effects their operations have on society. [..] The process by which corporations assume full responsibility for the effects their activities have on societ $y^{8}$.

Voluntary action by companies and their shareholders to embed this process in their production is not an effective remedy. Experience proves that they do not internalize their externalities voluntarily. The roadmap to improve sustainability of companies' business should necessarily include, among other solutions, mandatory duties for directors.

\section{New prospects in the world's largest economy?}

In 2018, US Senator Elizabeth Warren (D-Mass.) - a professor of Bankruptcy Law at Harvard Law School, who run for the US Democratic Presidential primaries

\footnotetext{
Porter M., Kramer M. Strategy and society: the link between competitive advantage and corporate social responsibility. Harvard Business Review, December, 2006, p. 5.

5 Sjafjel B., Richardson B. J. Company Law and Sustainability. Cambridge, Cambridge University Press, 2015, p. 324.

6 Henderson G. A fiduciary duty to minimize the corporation's environmental impacts. SSRN 2011. Available at: http://ssrn.com/abstract=1932032 [last viewed November 1, 2019].

7 Sjafjel B., Richardson B. J. 2015, p. 315.

8 Johnston A. Facing up to social cost: the real meaning of corporate social responsibility. Griffith Law Review, Vol. 20, 2011, p. 221.
} 
of 2020 - proposed the Accountable Capitalism Act ${ }^{9}$. Stakeholder governance is at the heart of the bill. A model in which corporations are run by, and accountable to, multiple groups of stakeholders, affirming that corporations should have a positive impact on society, mandating that employees have a meaningful voice in corporate governance, and ensuring that the directors of a corporation must take all groups of stakeholders into account when making big decisions about the business. In a Wall Street Journal op-ed, announcing her legislation, Senator Warren stated:

For much of U.S. history corporations sought to succeed in the marketplace, but they also recognized their obligations to employees, customers and the community.

The bill - whose importance, regardless of its unlikely approval, rests on the principles recognized within the largest economy in the world - would require of very large American corporations:

(1.) to obtain a federal charter as a "United States corporation", which obligates company directors to consider the interests of all corporate stakeholders: American corporations with more than $\$ 1$ billion in annual revenue must obtain a federal charter from a newly formed Office of United States Corporations at the Department of Commerce. The new federal charter obligates company directors to consider the interests of all corporate stakeholders - including employees, customers, shareholders, and the communities in which the company operates.

(2.) to empower workers through their election into the board of directors. Borrowing from the successful approach of Germany and other developed economies, a US corporation should ensure that no fewer than $40 \%$ of its directors would be selected by the corporation's employees.

(3.) to restrict the sales of company shares by the directors and officers of United States corporations: corporate executives are now compensated mostly in company equity, which gives them huge financial incentives to focus exclusively on shareholder returns. To ensure that they are focused on the long-term interests of all corporate stakeholders, the bill prohibits directors and officers of United States corporations from selling company shares within five years of receiving them or within three years of a company stock buyback.

The federal government could revoke the charter in case of repeated illegal conduct.

The core provisions are in Sec. 5, which states:

In discharging its duties [..] the board of directors:

(A) shall manage or direct the business

i) and affairs of the United States corporation in a manner that:

ii) seeks to create a general public benefit;

Palladino L., Karlsson K. The importance of replacing shareholder primacy with stakeholder corporate governance. The Roosevelt Institute, 2018. Available at: https://rooseveltinstitute.org/ wp-content/uploads/2018/10/Towards-\%E2\%80\%98Accountable-Capitalism\%E2\%80\%99-issuebrief.pdf [last viewed November 3, 2019]. 
iii) and balances the pecuniary interests of the shareholders of the United States corporation with the best interests of persons that are materially affected by the conduct of the United States corporation;

In carrying out such duties, the board shall consider the effects of any action or inaction on:

i) the shareholders of the United States corporation;

ii) the employees and workforce of the United States corporation;

iii) the subsidiaries of the United States corporation;

iv) the suppliers of the United States corporation;

v) the interests of customers and subsidiaries of the United States corporation as beneficiaries of the general public benefit purpose of the United States Corporation;

vi) community and societal factors, including those of each community in which offices or facilities of the United States corporation, subsidiaries or suppliers are located;

vii) the local and global environment;

viii) the short-term and long-term interests of the United States corporation.

\section{Some steps in the right direction}

Actually, the first legislation, ever, to provide specific directors' duties, which should take into account not only the shareholders' value maximization, is the UK Companies Act of 2006, which launched the so-called "enlightened shareholder value":

the idea that corporations should pursue shareholder wealth with a long-run orientation that seeks sustainable growth and profits based on responsible attention to the full range of relevant stakeholder interests ${ }^{10}$.

According to one of the most in-depth analysis of the "enlightened shareholder value":

[..] the interests of stakeholders are only relevant to the degree that they contribute to the goal of attaining maximization of the shareholder's wealth ${ }^{11}$.

10 Millon D. Enlightened shareholder value, social responsibility, and the redefinition of corporate purpose without law. Available at: https://ssrn.com/abstract=1625750 [last viewed October 31, 2019]. The "Purposeful Company" is another definition clearly depicted by the UK Big Innovation Centre report of 2015, when stating that "A purposeful company is inspired by a clear role in the world that offers it a reason for being - its purpose [..] Purpose ensures that a company is more than a web of transactions. Instead, purposeful companies contribute meaningfully to human betterment and create long-term value for all their stakeholders". Available at: http://www. biginnovationcentre-purposeful-company.com/wp-content/uploads/2017/11/feb-24_tpc_policyreport_final_printed.pdf [las viewed November 1, 2019].

11 Keay A. The Enlightened Shareholder Value Principle and Corporate Governance. Abington-New York, Routledge, 2013, p. 17 
Section 172 of the UK Companies Act, named "Duty to promote the success of the company", states that:

(1) A director of a company must act in the way he considers, in good faith, would be most likely to promote the success of the company for the benefit of its members as a whole, and in doing so have regard (amongst other matters) to -

(a) the likely consequences of any decision in the long term,

(b) the interests of the company's employees,

(c) the need to foster the company's business relationships with suppliers, customers and others,

(d) the impact of the company's operations on the community and the environment,

(e) the desirability of the company maintaining a reputation for high standards of business conduct, and

(f) the need to act fairly as between members of the company.

If it is true that

stakeholders' interests shall be taken into consideration by directors in so far as they enhance the value of the company and its shares,

no one can deny that

UK legislation is much far ahead compared to European jurisdictions that do not contemplate, require or even permit directors to have regard of stakeholders' interests in discharging their functions ${ }^{12}$.

In Canada, the seminal decision of the Supreme Court in BCE Inc. v. 1976 Debenture holders ${ }^{13}$ makes it clear that directors owe their duty to the corporation. In discharging this duty, directors are required to have fair regard to the interests of various stakeholders.

Italy has been the first EU country to introduce (in 2016) the Benefit Companies which, voluntarily,

beyond the purpose of dividing profits among its shareholders, pursue one or more common benefit purposes and act in a responsible, sustainable and transparent manner towards people, communities, territories, the environment, goods and cultural and social activities, bodies and associations and other bearers of other interests.

Such purposes are followed in a way that should balance the interests of the shareholders with those, which can be affected by the company activities. Approximately, two hundred benefit companies operate today in the country,

12 Bruno S. The "enlightened shareholder value" in UK companies ten years later: what the European Directive No. 2014/95/EC can do. SSRN 2015. Available at: https://ssrn.com/abstract=2674706 [last viewed October 29, 2019].

132008 SCC 69, 3 SCR 560. 
therefore, these are at present a rather minor phenomenon. The Italian reform is surely to be welcomed, although it entirely leaves the choice of taking into consideration other interests to shareholders. On the other hand, Italian "provisions of the Civil Code do not even mention stakeholders, nor contemplate the possibility that directors may take into consideration those interests" ${ }^{14}$.

The mandatory rule is, instead, the direction taken by the EU Directive 2014/95/UE, which imposes upon large groups of companies the disclosure of nonfinancial information.

\section{Conclusions}

The policies just reported and the increasing instances coming, worldwide, from the Company Law debate, make clear that incorporating stakeholders' interests in directors' duties is the most demanding and realistic horizon for any legislation. The time for spontaneous consideration of stakeholders' interests and for voluntarily internalization of companies' externalities is definitely over.

\section{BIBLIOGRAPHY}

\section{Literature}

1. Big Innovation Centre. The purposeful company. London, 2017. Available at: http://www. biginnovationcentre-purposeful-company.com/wp-content/uploads/2017/11/feb-24_tpc_ policy-report_final_printed.pdf [last viewed November 1, 2019].

2. Bratton W. W., Wachter M. L. Shareholder Primacy“s Corporatist Origins: Adolf Berle and "The Modern Corporation". Journal of Corporation Law, Vol. 34, 2008, p. 99.

3. Bruno S. The 'Enlightened Shareholder Value' in UK Companies Ten Years Later: What the European Directive N. 2014/95/EC Can Do. SSRN, 2015. Available at: https:// ssrn.com/abstract $=2674706$ [last viewed October 29, 2019].

4. Friedman M. The social responsibility of business is to increase its profits. The New York Times Magazine, September 13, 1970. Available at: http://umich.edu/ thecore/doc/Friedman.pdf [last viewed October 29, 2019].

5. Hansmann H., Kraakman R. The End of History for Corporate Law, Georgetown Law Journal, Vol. 89, 2001, p. 439.

6. Henderson G. A fiduciary duty to minimize the corporation's environmental impacts. SSRN, 2011. Available at: http://ssrn.com/abstract=1932032 [last viewed November 1, 2019].

7. Johnston A. Facing up to social cost: the real meaning of corporate social responsibility. Griffith Law Review, Vol. 20, 2011, p. 221.

8. Keay A. The Enlightened Shareholder Value Principle and Corporate Governance. AbingtonNew York, Routledge, 2013, p. 17

9. Macintosh J. C. C. The issues, effects and consequences of the Berle-Dodd debate, 1932-1932. Accounting, Organizations and Society, Vol. 24, 1999, pp. 139-153.

${ }_{14}$ Bruno S. 2015, p. 8. 
10. Millon D. Enlightened shareholder value, social responsibility, and the redefinition of corporate purpose without law. SSRN, 2010. Available at: https://ssrn.com/abstract=1625750 [last viewed October 31, 2019].

11. O'Kelley C. R. T., Merrick Dodd and the great depression: a few historical corrections. SSRN, 2019. Available at: https://ssrn.com/abstract=3325481 [last viewed April 8, 2020].

12. Palladino L., Karlsson K. The importance of replacing shareholder primacy with stakeholder corporate governance. The Roosevelt Institute, 2018. Available at: https:// rooseveltinstitute.org/wp-content/uploads/2018/10/Towards \%E2\%80\%98AccountableCapitalism\%E2\%80\%99-issue-brief.pdf [last viewed November 3, 2019].

13. Porter M., Kramer M. Strategy and society: the link between competitive advantage and corporate social responsibility. Harvard Business Review, 2006, p. 78.

14. Sjafjel B., Richardson B. J. Company Law and sustainability, Cambridge, Cambridge University Press, 2015. 